\title{
LEGAL PROTECTION FOR ILLEGAL MIGRANT DOMESTIC WORKERS UNDER THE ASEAN REGULATIONS AND ITS IMPLICATION FOR INDONESIA
}

\author{
Arini Azka Muthia \\ Faculty of Law, University of Bengkulu, Indonesia \\ Correspondence: aazkamuthia@gmail.com
}

\begin{abstract}
Domestic work is an essential source of livelihood for women and men in Southeast Asia and requires legal protection, including for illegal migrant domestic worker. The ASEAN Consensus on Protection and Promotion of the Rights of Migrant Worker 2017 regulates the protection of migrant workers, including illegal migrant workers in the domestic sector. This research discusses the implications of the ASEAN Consensus on the Protection and Promotion of the Rights of Migrant Worker 2017 for the ASEAN member countries, particularly Indonesia. This research applies a juridical-normative approach focusing on the legal materials related to the protection of domestic workers. This research also applies the statute approach. The data are analyzed qualitatively. This research concludes that the ASEAN Consensus 2017 requires close cooperation between ASEAN countries in resolving cases of illegal migrant workers through preventive measures under national laws, regulations and policies that apply in ASEAN Member Countries. Indonesia is expected to be able to implement what was agreed in the ASEAN Consensus 2017 on national legislation and other domestic policies related to the protection and promotion of migrant workers' rights in the domestic sector. Efforts in implementing the ASEAN Consensus 2017 on migrant workers for Indonesia can be pursued in two ways, efforts to improve internally and externally.
\end{abstract}

Keywords : ASEAN, Domestic Worker, Illegal, Migrant, Protection.

Submitted : 4 January 2020 | Revised : 28 March 2020| Accepted : 4 April 2020

\section{INTRODUCTION}

The high cost of living necessities and the minimal number of jobs in the country, which is influenced by the low level of education, encourages most people to leave their home countries and look for work in other countries. Globally, the increasing need for human resources to do work in the domestic sector is a massive opportunity for people who want to work abroad. In reality, the risk of work is very high, and protection is weak. The most common problems encountered in employment in the domestic sector include low wages, long working hours, heavy workloads, no weekly rest days, and very vulnerable to psychological, physical or sexual abuse. ${ }^{1}$

\footnotetext{
${ }^{1}$ Glenda Labadie-Jackson, "Reflections on Domestic Work and The Feminization of Migration," Campbell Law Review 31, no . 1 (2008), 67.
} 
Indonesia is one of the largest sending countries for workers in the domestic sector to ASEAN countries and throughout the world to reach the number of 93,124 people in $2018 .^{2}$ As a result of the number of workers, remittances (transfers of money made by workers to Indonesia) amounted to $\$$ $3,650,443,254$ in 2018. Even so beneficial for Indonesia, but throughout 2018 there were still many complaints about problems that occurred, including the undocumented TKI totaling 441 cases, which each year increased compared to previous years, in 2014 there were 73 cases, in 2015 there were 81 cases, in 2016 there were 133 cases, in 2017 there were 373 cases, and in 2018 there were 441 cases.

Cases of complaints of undocumented workers are one form of illegal migration. The latest case that is hotly discussed is the death of an Indonesian Migrant Worker named Renova Hutapea, who was allegedly mistreated by her employer in Malaysia. ${ }^{3}$ This case was the result of illegal migration practices facilitated by a broker named Hi'is Darsini, a resident of Tanjung Sengkuang, Batuampar, Batam. Darsini sent Renova Hutapea, who was promised to work in a nursing home with a wage of RM 1200, but in reality, Renova was employed in a restaurant. Darsini handles identity, such as family cards (KK), Resident Identity Cards (KTP), passports. The Renova placement process is carried out by Darsini without going through an official distributor company and does not have official documentation. Renova Hutapea finally died on July 2, 2019, after being treated as a result of the torture suffered by the victim while working in Malaysia.

Besides, news can also be found explaining that there is a widespread occurrence of sending migrant workers from Indonesia illegally. One case was thwarted by Sub Directorate IV protection unit of women and children (PPA) against the departure of 29 illegal Indonesian migrant workers from NTT to Malaysia last August. They were promised to work in Malaysia with a decent salary and generally work in the plantation, livestock, and household assistant. ${ }^{4}$ Besides thwarting the illegal Indonesian Migrant Workers, two managers were arrested, who accommodated the arrival of Indonesian Migrant Workers. The case above shows that up to now, the case of sending illegal

\footnotetext{
2 "Data Penempatan dan Perlindungan PMI periode tahun 2018 [Data on Placement and Protection of Indonesian Migrant Workers for 2018]," National Agency for Placement and Protection of. Indonesian Overseas Workers (BNP2TKI), accessed August 21, 2019 http://portal.bnp2tki.go.id/uploads/data/data_12-032019 094615_Laporan_Pengolahan_Data_BNP2TKI_2018.pdf.

3 "Bandar TKI Ilegal yang Tewas Dianiaya Majikan di Malaysia ditangkap [The dealer of an Illegal Migrant Worker Killed Abused Employer in Malaysia has been arrested]," accessed August 20 2019, https:// daerah.sindonews.com/read/1419773/174/bandar-tki-ilegal-yang-tewas-dianiaya-majikan-di-malaysia-ditangkap-1562934269. Accessed August 202019.

4 "29 TKI ilegal gagal ke Malaysia [29 Illegal migrant workers fail to Malaysia]," BatamPos, accessed August, 2019, https://batampos.co.id/2019/08/27/29-tki-ilegal-gagal-ke-malaysia/.
} 
Indonesian Migrant Workers is still occurring and requires the dangerous handling of both those handled sending and receiving countries.

Illegal migration from Indonesia is a result of several interrelated factors, including a large number of brokers and unregistered recruitment agents in rural areas, lack of knowledge among Indonesian migrant workers about proper migration procedures and migrant human rights, weak government involvement in providing information and protection for Indonesian migrant workers, weak law enforcement and failure to prosecute those involved in illegal and immoral recruitment practices. ${ }^{5}$

In connection with the problems that occur with migrant workers, ASEAN, as an international organization of Southeast Asian Countries, must protect workers in the domestic sector. That is because some ASEAN member countries are destination countries and countries that send workers in the domestic sector to and from around the world. The sending countries of workers in the domestic sector are the Philippines and Indonesia. In November 2017, ASEAN issued a regulation which was the result of the agreement of ASEAN countries regarding the legal protection of migrant workers by the title Asean Consensus on the Protection and Promotion of the Right of Migrant Workers. The ASEAN Agreement regulates in detail related to the protection of migrant workers. Also, it sets obligations for sending and receiving countries, especially in ASEAN, without exception to illegal migrant workers. This paper aims to analyze the legal protection of illegal migrant workers in the domestic sector in the ASEAN Regulations and the Implications for Indonesia.

\section{ANALYSIS AND DISCUSSION}

Permanent and continuous relations between nations in various fields of life result in a need to bring order, regulate, and maintain such relations. ${ }^{6}$ International law defines as a set of rules and regulations that bind and regulate relations between states and other legal subjects in the international community. ${ }^{7}$ More specifically, international law is seen as an orderly universal law. As Jenks explained in his book, international law is a universal law for

\footnotetext{
5 "Migrasi Tenaga Kerja dari Indonesia (Gambaran Umum Migrasi Tenaga Kerja Indonesia di Beberapa Negara Tujuan di Asia dan Timur Tengah) [Labor Migration from Indonesia (Overview of Indonesian Labor Migration in Several Destination Countries in Asia and the Middle East)]," IOM, accessed August 25, 2019, https://www.iom.int/jahia/webdav/shared/shared/mainsite/published_docs/Final-LM-ReportBahasa-Indonesia.pdf.

${ }^{6}$ Mochtar Kusumaatmadja, Pengantar Hukum Internasional [Introduction to International Law] (Bandung: PT. Alumni, 2012), 13.

7 Boer Mauna, Hukum Internasional (Pengertian Peranan dan Fungsi dalam Era Dinamika Global)[International Law (Understanding the Role and Function in the Era of Global Dynamics)] (Bandung: PT Alumni, 2005), 3.
} 
humankind regulating relations between nations. ${ }^{8}$ Universal law for humankind is the law that organizes the world community, the law that guarantees the rights and obligations of individual citizens, as well as the laws governing various fields which are judged to require uniform international regulations. ${ }^{9}$ Civilized nations recognize the principle of the same law as the incarnation of natural law (natuurrecht), which requires that the nations of the world live side by side peacefully. ${ }^{10}$

According to J.G. Starke, international law's general purpose is more towards creating order than what the system of international relations is looking for, fairer in subsequent developments have been seen about efforts to achieve goals that are compatible with justice in countries. ${ }^{11}$ Apart from considering countries accepting the fair solution, modern nations' laws ask for help for humanity. ${ }^{12}$

Attempts to bring about justice for humanity command respect for human rights and fundamental freedoms for all without distinction. According to Jack Donnely, human rights are defined as rights possessed by humans solely because they are human. ${ }^{13}$ Humans have these rights not because they were given to them by the community or based on positive law but only based on their dignity as human beings. ${ }^{14}$ In this sense, even though each person is born with different skin colour, gender, language, culture, and citizenship, he still has these rights, this is the nature of the universality of human rights. ${ }^{15}$

Internationally, the Universal Declaration of Human Rights (UDHR) is the first element of the International Bill of Rights, which is the core of human rights protection in the world community. ${ }^{16}$ The UDHR contains details about civil, political, economic, social, and cultural rights that must be respected and promoted by every individual and organ in society (every individual and every organ of society).

In economic field, Article 23 of the UDHR provides that Everyone has the right to work, has free choice of employment, has just and favourable condi-

\footnotetext{
${ }^{8}$ C. W. Jenks, The Common Law of Mankind (London: Stevens \& Sons, 1958), 58.

${ }^{9}$ Ibid.

${ }^{10}$ Kusumaatmadja, Pengantar Hukum Internasional, 15.

${ }^{11}$ J.G. Starke, Pengantar Hukum Internasional [Introduction to International Law] (Jakarta : Sinar Grafika, 2010), 6 .

12 Ibid.

${ }^{13}$ Jack Donnely, Universal Human Rights in Theory and Practice (Ithaca and London : Cornell University Press, 2003), 7.

${ }^{14}$ Ibid.

${ }^{15}$ Rhona K.M. Smith, et al. Hukum Hak Asasi Manusia [Human Rights Law] (Yogyakarta: Center for Human Rights Studies at the Islamic University of Indonesia, 2008). 11.

16 Manfred Nowak, U.N. Covenant on Civil and Political Rights: CCPR Commentary (Kehl am Rhein; Strasbourg; Arlington: Engel, 1993). XVII.
} 
tions of work and to protection against unemployment; Everyone, without any discrimination, has the right to equal pay for equal work; Everyone who works has the right to just and favourable remuneration ensuring for himself and his family an existence worthy of human dignity, and supplemented, if necessary, by other means of social protection; Everyone has the right to form and to join trade unions for the protection of his interests. Economic rights are regulated in the UDHR, furthermore comprehensively arranged in the Covenant on Social and Cultural Economic Rights (The International Covenant on Economics, Social and Cultural Rights; 1966). The rights stipulated herein are the right to work, the right to conditions of work under trade unions, the right to social security, the right to an adequate standard of living, the right to enjoy physical and mental health, the right to education, and the right to participate in cultural life.

Enterprises to promote and protect labour rights, including workers in the domestic sector, are also carried out by the ILO as an international labour organization. The ILO role can be seen, including in formulating policies or programs to promote human rights to improve working conditions, increase employment opportunities, set international standards (both conventions and recommendations) in the area of employment, and monitor national implementation in various countries. ${ }^{17}$ The Workers in Domestic Sector Convention, issued by the ILO in 2011, regulates labour protection standards in the domestic sector by what is mandated in the ICESCR. The protection standards include providing fair wages, decent living, safe and healthy working conditions, rest, holidays, and restrictions on working hours.

Regional organizations also strive for the protection of human rights. The fundamental purpose behind each regional organization is to encourage cooperation between member states in developing general solutions to various problems. Regional organizations have a role in promoting universal goals in a particular geographical area through established regional bodies..$^{18}$

ASEAN, as a regional organization, has a substantial commitment to the protection of human rights. We can see its commitment in the 2007 ASEAN Charter, which later became the framework for ASEAN. The Opening of the ASEAN Charter explained that to be able to live in a region that has eternal peace, security and stability, sustainable economic growth, shared prosperity and social progress, and to advance shared interests, ideals and aspirations, ASEAN countries must comply several principles, including the principle of

\footnotetext{
17 European Training and Research Centre for Human Rights and Democracy, Understanding human rights: a manual on human rights education) (German: Neuer Wissenschaftlicher Verlag, 2006), 29.

${ }_{18}$ A. Leroy Bennett, International organizations (principles \& Issues) (New Jersey : Prentice Hall, Englewood Cliffs, 1991), 222.
} 
respect and protection of human rights and fundamental freedoms.

In order to realize an ASEAN Community that is politically integrated, economically integrated, and can be socially responsible, it requires ASEAN to create a single market and production base that is stable, prosperous, competitive and economically integrated. This integrated effort must be supported through sufficient facilities for trade and investment that provide a free flow of goods, services and investment, the movement of business people, professional workers, talented workers and labourers, and more open capital flows. Based on the above, ASEAN desires the flow of services, skilled workers, and qualified workers, and expects the flow of workers, including workers in the domestic sector in particular and migrant workers in general.

Employment in the domestic sector is essential for decent women and men in Southeast Asia, specifically for women who come from villages with low levels of education and skills that can be traded. Therefore, ASEAN is obliged to guarantee the protection of human rights and fundamental freedoms for workers in the migrant domestic sector who are part of migrant workers. Based on this, ASEAN member countries commit to the promotion and protection of human rights, which can support one of them by cooperating between ASEAN member countries, relevant national, regional and international institutions, under the ASEAN Charter. The explanation was conveyed in Article 39 of the ASEAN Declaration of Human Rights, as follows:

"ASEAN Member States share a common interest in and commitment to the promotion and protection of human rights and fundamental freedoms which shall be achieved through, among other things, cooperation with one another as well as with relevant national, regional and international institutions/organizations, in accordance with the ASEAN Charter".

Based on the explanation of article 39, cooperation between ASEAN member countries is a necessity in achieving the goal of ASEAN and ASEAN member countries have committed to this, especially in the field of promotion and protection of human rights and fundamental freedoms. Furthermore, in general, efforts to regulate the promotion and protection of workers in the domestic sector that have been carried out by ASEAN can be found in the ASEAN Declaration on the Protection and Promotion of the Rights of Migrant Workers (ASEAN Declaration on the Protection and Promotion of the Rights of Migrant) Workers). Nevertheless, the regulation was considered insufficient, until November 14, 2017, in Manila, the Philippines, ASEAN countries agreed on an instrument of protection and promotion of migrant workers' rights entitled ASEAN Consensus on Protection and Promotion of the Rights 
of Migrant Workers which Furthermore, this discussion will be referred to as the 2017 ASEAN Consensus on migrant workers. Countries that agreed on the consensus were Brunei Darussalam, Cambodia, Indonesia, Laos, Malaysia, Myanmar, the Philippines, Singapore, Thailand, Vietnam.

In substance, the 2017 ASEAN Consensus on migrant workers consists of 8 chapters and 62 Articles. Part one explains the General Principles, part two explains definitions, part three explains the fundamental rights of migrant workers and the members of their families, part four governs the specific rights of migrant workers, part five regulates obligations of sending states, part six regulates obligations of receiving states, part seven regulates commitments of ASEAN member states, and part eight regulates amendments.

In part one, the ASEAN Consensus 2017 on Migrant Workers regulates the General Principles / general principles, which explain that in order to implement the consensus, ASEAN Member States will act under the general principles adopted, particularly:

Respect for ASEAN principles, as stated in Article 2 of the ASEAN Charter.

Strengthening the political-security, economic and socio-cultural pillars of the ASEAN Community by promoting the full potential and dignity of migrant workers in a climate of freedom, equality, and stability under the laws, regulations, and policies of each ASEAN Member State.

Recognizing that migrant workers have fundamental rights as provided in international and regional treaties in which ASEAN member countries are members, based on national laws, regulations, and policies in force in ASEAN member countries.

Uphold the fundamental rights and dignity of migrant workers without damaging the application of the laws, regulations, and policies of the Receiving State.

Uphold fair treatment concerning gender and nationality, and protect and promote the rights of migrant workers, especially women, by the obligations of ASEAN member states under appropriate international instruments in which these countries become member countries.

Take a constructive, non-confrontational, and cooperative approach to enhance the protection and promotion of migrant workers' rights. 
In point two, this general principle states that the ASEAN Consensus 2017 on migrant workers not only regulates the protection of documented migrant workers but also provides protection for undocumented migrant workers caused not by their own mistakes.

Undocumented migrant workers occur in one of the categories of illegal migrant workers in the migration process. Illegal migration means a movement that occurs outside the norms of rules in the country of origin, transit, and destination. ${ }^{19}$ From the perspective of the destination country, migration includes: coming, living, or working in a country illegally, meaning that migrants do not have the documents required under immigration regulations to enter, live and work in a country at that time..$^{20}$ From the perspective of the country of origin, illegal migration occurs when a country's citizen crosses into an international border without a valid travel document or does not meet the administrative requirements for going to that country. ${ }^{21}$

There are three types of illegal migration activities, (1) entering and leaving a country illegally, (2) staying unofficially; and (3) work illegally. ${ }^{22} \mathrm{Be}-$ sides, most illegal migrants enter officially but lose their official status in the destination country. ${ }^{23} \mathrm{~A}$ migrant may lose his official status for several reasons, including staying longer than allowed by his visa, accepting another job, taking a different form of work than stated in his visa, or escaping secretly from his employer. ${ }^{24}$

A worker in the domestic sector does domestic work in a working relationship to get wages. Hence illegal migrant workers in the domestic sector in this paper are interpreted as someone who is engaged in domestic work in a working relationship by receiving wages outside the territory of the Republic of Indonesia but legally does not have the documents required under immigration regulations to enter, live and work in a country.

Data shows that around $10-15 \%$ of migrant workers internationally are illegal workers. ${ }^{25}$ Most informal migrations are achieved solely by migrant workers in obtaining employment, for example, through family or personal connections, both before and after migrating. Globally there is no accurate data on the number of illegal migrant workers in the domestic sector, and this

\footnotetext{
19 International Organization for Migration, Migrasi Tenaga Kerja dari Indonesia [Labor Migration from Indonesia] (Jakarta: IOM, 2010), 7.

20 Ibid

21 Ibid

22 Ibid

23 Ibid

24 Ibid

${ }^{25} \mathrm{OHCHR}$, Behind Closed doors protecting and promoting the human rights of migrant domestic workers in a irregular situation (New York and Geneva, 2015), 3.
} 
is due to several reasons. ${ }^{26}$ First, workers in the domestic sector are informal types of work and are not sponsored as workers in many countries; second, illegal migrant workers are not registered in the country where they work and are not included in official data. ${ }^{27}$ Besides, migrant workers in the domestic sector do not want to provide information to relevant officials, because that would reveal their status. The lack of data information is one reason why migrant workers' position in the domestic sector is not a paramount concern. ${ }^{28}$

Accurate data related to the number of illegal migrant workers in the domestic sector, especially in ASEAN, is complicated. However, the World Bank estimates that there are undocumented migrant workers in Malaysia amounting to 1 million people, and most of them are workers in the domestic sector. ${ }^{29}$ Malaysia is the leading destination country for workers in the domestic sector after Brunei Darussalam, Singapore, and Thailand. ${ }^{30}$ Sending countries of migrant workers in the domestic sector are Cambodia, Indonesia, and the Philippines. ${ }^{31}$ In Singapore, the majority of domestic workers have migrated from Indonesia, Myanmar, and the Philippines. ${ }^{32}$ Thailand employs migrant workers in the domestic sector from Cambodia, Laos, and Myanmar. Data obtained from BNP2TKI (National Agency for the Placement and Protection of Indonesian Workers) shows that in April to June 2019, Indonesia sent 26,668 migrant workers dominated by domestic workers to the ASEAN country with the following distribution:

Table 1. The destination countries of Indonesian migrant workers in ASEAN in April-June 2019

\begin{tabular}{|l|l|c|}
\hline No & Country of destination & April-Juni 2019 \\
\hline 1 & Malaysia & 20.367 people \\
\hline 2 & Singapore & 5.070 people \\
\hline 3 & Brunei Darussalam & 1.231 people \\
\hline \multicolumn{2}{|c|}{ Total } & 26.668 people \\
\hline
\end{tabular}

Based on these data, Malaysia is the most desirable destination country for migrant workers in the domestic sector, due to linguistic, cultural and historical relationships that allow for more natural cooperation between employers

\footnotetext{
${ }^{26}$ Ibid

${ }^{27}$ Ibid

${ }^{28}$ Ibid

${ }^{29}$ Ridwan Wahyudi, "Illegal Journey: The Indonesian Undocumented Migrant Workers to Malaysia," $J u$ rnal Populasi 25, no. 4 (2017): 25.

${ }^{30} \mathrm{Ibid}$.

${ }^{31} \mathrm{Ibid}$

${ }^{32}$ Ibid.
} 
and migrant workers. ${ }^{33}$

The high number of Indonesian citizens who are interested in coming to Malaysia can be seen from a Back for Good program launched by the Malaysian Directorate General of Immigration for foreign visitors without permission or PATI. The Back for Good Program is a voluntary repatriation program for foreigners without permission (PATI). The program has been announced since July 11, 2019, by the Malaysian Immigration Office (JIM) and took effect from August 1 to December 31, 2019. Indonesian migrant workers and Indonesian citizens who participate in the program voluntarily will not be detained in immigration prisons. The number of people who registered to take part in this program was around 138,901 people. The request of Indonesian citizens was highest at 53,328 people, Bangladesh were 38,734, India were 22,964, Myanmar were 6,923, and the surplus came from other countries. A total of 53,328 people who came from Indonesia and wished to join the program were mostly thought to be illegal migrant workers in the domestic sector. ${ }^{34}$ Besides data submitted by BNP2TKI related to the return of illegal migrant workers over the past four years is as follows: ${ }^{35}$

Tabel 2. Data on Return of Troubled Migrant Workers in the

Last Four Years Period

\begin{tabular}{|c|c|c|}
\hline No & \multicolumn{1}{|l|}{ Year } & Number of people \\
\hline 1 & 2015 & 19.167 \\
\hline 2 & 2016 & 15.291 \\
\hline 3 & 2017 & 18.463 \\
\hline 4 & 2018 & 14.349 \\
\hline Total & & $\mathbf{5 3 . 2 8 4}$ \\
\hline
\end{tabular}

The number of illegal migrant workers during the past four years has decreased from year to year. However, this is inversely proportional to the number of Indonesian citizens who register to join the Back for Good program for foreign migrants without permission in Malaysia. The following causes seem to be among the most important: ${ }^{36}$

1) Restrictive immigration policies in receiving countries

2) Acute poverty and unemployment problems in countries of origin re-

\footnotetext{
33 IOM, "Migrasi Tenaga Kerja dari Indonesia".

34 "Program Back for Good untuk PATI kembali ke Negara Asal [The Back for Good program for PATI returns to the Country of Origin]," Buruh Migran, August 13, 2019, accessed June 25 2020. https://buruhmigran.or.id/2019/08/13/program-back-for-good-untuk-pati-kembali-ke-negara-asal/.

35 Data source: Subdirectorate of Indonesian Migrant Worker Return Service, BNP2TKI.

36 Piyasiri Wickramasekera, Asian Labour Migration: Issues and Challenges in an Era of Globalization (Geneva: ILO, 2002), 22.
} 
sulting in acute emigration pressures

3) Political suppression and armed conflict

4) Malpractices of private recruitment agencies

5) High migration costs

6) Activities of criminal gangs and traffickers

7) Bureaucratic procedures which add to high costs of emigration

In particular, the high number of illegal Indonesian migrant workers in Malaysia, based on the above causative factors, is influenced by four main factors:

a) Restrictive immigration policies in receiving countries. For example, the conditions that must be met by someone when they want to become official workers in the domestic sector are: signing an Employment Contract with an employer; have a work pass that is managed by the employer and be subject to payment per year (levy); Have a Foreign Worker Identification Card issued by the Malaysian Government; and Work for an employer whose name and address are listed in the Work Permit. ${ }^{37}$ Although the conditions of work for an employer whose name and address are listed in the Work Permit were initially fulfilled, highly exploitative working conditions, physical and psychological violence or unpaid salary cause migrant workers to prefer leaving the employer and losing their official status, whereas a work permit is an official status requirement relating to employers.

b) Acute poverty and unemployment problems in countries of origin resulting in acute emigration pressures. BPS (Central Statistics Agency) announced an increase in the number of poor people in March 2015, as many as 17.94 million people were deficient in rural areas and 10.67 million people who were deficient in urban areas. Thus the number of poor people amounted to 28.59 million people. ${ }^{38}$ The most significant increase in the number of poor people occurred in rural areas. The number of poor people increased by 86,000 people in six months since September 2014, totaling 27.73 million poor people (BPS RI, 2015). ${ }^{39}$ In addition to a large number of poor people in Indonesia, the number of unemployed people is also very high. The lack of employment is a driving factor for Indonesian migrant workers. The increasing number of unemployed people proves that Indonesia's employment opportuni-

\footnotetext{
${ }^{37}$ Indonesian Embassy at Kuala Lumpur, "Bagaimana Menjadi Tenaga Kerja Indonesia [How to Become an Indonesian Worker]," Kedutaan Besar Indonesia Kuala Lumpur, February 24, 2017, acessed June 29 2020, http://kbrikualalumpur.org/w/2017/02/24/bagaimana-menjadi-tenaga-kerja-indonesia/.

38 Ibid

39 Ibid
} 
ties are limited, especially for people with low education, thus making people look for work in other countries even at risk. Malpractices of private recruitment agencies.

c) Violations committed by private recruitment include arresting or forcing people to do work that they do not want to do, such as becoming sex workers or holding without documents. ${ }^{40}$ For example, the case of human trafficking in East Nusa Tenggara (NTT) has increased very high over the past 12 years, even though NTT only sends 2,000-4,000 people each year from six million workers throughout Indonesia migrate to neighbouring countries. The cause of the high number of problems is due to the lack of professional recruitment companies in the Province. Hundreds of recruitment companies are registered, only 40 are still active, and only one has a training center in East Nusa Tenggara. Based on the data, it is known that departing migrant workers do not meet the requirements, and prospective workers receive almost no training and debriefing. Besides, it was found that prospective workers only stayed two or three days in the company's shelter and were immediately flown to the destination country. ${ }^{41}$

d) High migration costs. The cost of migration is essential for migrant workers if they want to work across the country. Financial readiness will affect which path to choose. For example, migration costs that must be prepared are regulated in a Decree of the Minister of Manpower and Transmigration of the Republic of Indonesia Number Kep. 152 / MEN / VI / 2011 concerning the Placement and Protection Costs for Prospective Indonesian Workers in Malaysia. In the rules mentioned costs that must be borne by Indonesian Workers such as Medical check-ups in Indonesia; Transportation costs from the area of origin of migrant workers to the port of Indonesian embarkation; Visa application fees at Malaysian representatives in Indonesia; Cost of arranging travel documents; Insurance; TKI Development and Protection Funds; Job training (50\%); Competition test; Accommodation; Services for Implementing Private TKI Placement, all of which amount to Rp $5,040,000 .{ }^{42}$ Besides, there are three additional fees set by the Malay-

\footnotetext{
40 M. Ridho Amrullah, "Kebijakan Ketenagakerjaan terkait Pencegahan TPPO: Migrasi Aman, UU 18/2017, Permenaker No. 9 Tahun 2019 dan 10 Tahun 2019, dan Sistem Penempatan Satu Kanal [Employment Policy related to TPPO prevention: Safe Migration, Law 18/2017, Permenaker No. 9 of 2019 and 10 of 2019 and the One Channel Placement System]," accessed June 26, 2020. https:/e-learningtppo.kemenpppa.go.id/pluginfile.php/455/mod_resource/content/1/2.\%20Materi\%20Kementerian\%20Ketenagakerjaan\%20-\%20Rakornas\%20GT\%20PP\%20TPPO \%20NTT\%202019.pdf.

${ }_{41}$ Ibid.

42 "Protes Pungutan TKI di Malaysia, Pemerintah Indonesia Menggertak [Protest on the charge for Indonesian migrant workers in Malaysia, the Indonesian government bluffed]," Tempo, May 5, 2017, accessed
} 
sian Government. The first is a one-door visa policy through a third party contracted by Malaysia. Visa fees amount to Rp. 882,000. Additional fees from the Malaysian Government contradicts the Minister of Manpower Decree in 2011, which states that the Malaysian labour migrant visa fee is only IDR 45,000. Second, the Malaysian version of the health check (Foreign Worker Centralized Management System) at the cost of Rp 450,000. The third is the immigration permit (Immigration Security Clearance / ISC) at Rp 418,000. Through ISC, prospective migrant workers are required to record fingerprint data and face photographs at companies that work with Malaysian Immigration and then send them to Malaysia. Enormous costs cause migrant workers to choose against the law because it is more practical and profitable.

Taking the migration path against the law, although considered beneficial, can have adverse effects. First, migrant workers will become victims of being denied their rights by employers, starting with wages that are not following standards and other rights. Second, migrant workers will become victims of blackmail by local mafias or criminal gangs. The employer will work with the negligent party to report the migrant worker to the police, to avoid payment of wages, even though the worker has sometimes worked long enough. Third, furthermore, the migration that is not following the provisions will cause strained relations between countries, both sending and receiving countries. The recipient country government does not feel obliged to provide proper treatment to workers. Fourth, migrant workers will have a very high fear if known by the authorities; this causes the weak protection that migrant workers will obtain.

Based on the explanation, it is expected that illegal migration, especially in the domestic sector, can be minimized or even eradicated because it can cause fundamental human rights violations for migrant workers. Migration that should be sought is safe and following applicable law, so that dignity protection can be provided.

In general, the settlement related to the problem of illegal migrant workers contained in The Bangkok Declaration on Irregular Migration (International Symposium on Migration "Towards Regional Cooperation on Irregular / Undocumented Migration" 21-23 April 1999), that states: first, The fundamental human rights of all migrant workers are covered by universal human rights instruments and ILO's core Conventions even if they are not ratified; Second, Countries of origin and host countries should cooperate in curbing irregu-

June 28, 2020, https://nasional.tempo.co/read/872434/protes-pungutan-tki-di-malaysia-pemerintah-indonesia-menggertak. 
lar migration; Third, The root causes of irregular migration flows should be addressed. One major cause is that migration laws and policies in receiving countries are out of line with actual labour market needs Fourth, The safe return of irregular migrants in conditions of dignity should be ensured in case they cannot be regularized; Fifth, Countries of origin should try to reduce emigration pressures by local development strategies.

In line with the Bangkok Declaration, on the ASEAN scale, the ASEAN Consensus 2017 on migrant workers also deals explicitly with illegal migrant workers, in the seventh section of articles 56 and 57 stating the following:

"For humanitarian reasons, closely cooperate to resolve the cases of migrant workers who, through no fault of their own, have subsequently become undocumented; Nothing shall be interpreted as implying the regularization of the situation of undocumented migrant workers. Take measures to prevent and curb the flow of undocumented migrant workers and explore cooperation and coordinating among ASEAN member states in assisting those who are in need of protection subject to prevailing national laws, regulations and policies of ASEAN member states."

Based on articles 56 and 57, it can be interpreted that there should be close cooperation between ASEAN countries in resolving migrant workers who are not their fault, and then become undocumented. Also, steps must be taken to prevent and stop the flow of undocumented migrant workers through cooperation and coordination between the ASEAN Member States in assisting those who need protection under national laws, regulations, and policies in effect in ASEAN Member Countries. Thus, in addition to the ASEAN countries' regional cooperation efforts, ASEAN also prioritizes the existence of diplomatic channels or cooperation of countries precisely so that the resulting provisions have the binding power as hard law. From the elaboration of the 2017 ASEAN Consensus on Migrant Workers and in the effort to prevent and protect illegal migrant workers in the domestic sector, Indonesia, which is appointing a migrant worker sending country in the domestic sector in ASEAN, must endeavour improvements internally and externally.

The intentional internal effort is to improve domestic regulations so that they are in sync with what has been agreed in the 2017 ASEAN Consensus on Migrant Workers and seek to implement them. Based on the principal matters regulated in the 2017 ASEAN Consensus on Migrant Workers, the efforts that can be made are:

a) The State of Indonesia must fulfil the fundamental rights of everyone in accessing information relating to employment available to migrant 
workers in the domestic sector, recruitment procedures, institutions that deal with rights, obligations, and sanctions in force. The information must be accurate and easily accessible to the regions;

b) The State of Indonesia is expected to simplify the administrative process related to the placement of migrant workers in the domestic sector.

c) The State of Indonesia is expected to set reasonable costs for workers in the domestic sector, both for the benefit of passports and other documentation and prohibiting any party from charging excessive recruitment fees.

d) The State of Indonesia is obliged to ensure that migrant worker in the domestic sector sign written work contracts and appropriate documentation in a language that can be understood by both parties.

The intentional external effort is revamping through diplomacy or cooperation of countries specifically through the evaluation of existing bilateral agreements and renewing them according to the latest needs. Besides, Indonesia must strive to build bilateral agreements with other recipient countries for migrant workers in the domestic sector. In its implementation, Indonesia currently has only two international agreements between Indonesia and countries in ASEAN, namely with Malaysia entitled the MoU between the Government of the Republic of Indonesia and the Government of Malaysia on the Recruitment and Placement of Indonesian Domestic Workers and renewed with Letter of Intent for The Amendment to the Memorandum of Understanding on the Recruitment and Placement of Indonesian Domestic Workers 2006 on May 182010 in Putrajaya, Malaysia, as well as an agreement with the Philippines entitled Joint Declaration of the Government of the Republic of Indonesia and the Government of the Republic of the Philippines on the Protection of Migrants and Migrant Workers in 2015 in Manila, Philippines.

Indonesia already has an agreement between Indonesia and Malaysia, and the agreement is deemed inappropriate. In addition to the expiration of the agreement, the substance must also be substantially adjusted to the latest developments produced by international agreements of human rights, agreements made by the ILO, and the agreements of ASEAN.

The agreement between Indonesia and Malaysia regarding the recruitment and placement of migrant workers in the domestic sector has made several changes, starting from the MoU agreed between Indonesia and Malaysia from 2004 to 2011. The MoU in 2004 became a revision of the MoU for the placement of migrant workers in the domestic sector. However, the MoU in 2004 
was unable to reduce the case of migrant workers in the domestic sector that occurred because it did not regulate related to wage standards, leave entitlements, and access to passports. The $2004 \mathrm{MoU}$ was no longer significant to the existing conditions, thus encouraging the Government to revise it in 2006. The MoU in 2006 was also a response to the conditions experienced by migrant workers in the domestic sector. However, with many cases occurring, the MoU in 2006 is considered unable to guarantee the fundamental rights of migrant workers in the domestic sector because it only focuses on technical regulations for the placement of migrant workers in the domestic sector and there are no clauses that explain the protection of rights for migrant workers in the domestic sector.

In 2011, the $2006 \mathrm{MoU}$ was amended with necessary adjustments. In the $2011 \mathrm{MoU}$, changes made were related to salary, leave rights, the right to hold their passports for migrant workers in the domestic sector. The two countries agreed to form a Joint Task Force (JTF), as stated in article 133, which is to act as a task force that oversees the implementation of the existing MoU, JTF is represented by Indonesia and Malaysia. Periodically there will be the supervision of the implementation of the MoU and completion right for the problems that arise related to migrant worker in Malaysia. Article 10 explains that the $2006 \mathrm{MoU}$ was extended for five years from the signing of the protocol on May 30, 2011, and the MoU was declared no longer valid after May 30, 2016.

To protect illegal migrant workers in the domestic sector, especially with the largest received country of migrant workers in the domestic sector, Malaysia, the Government of Indonesia is expected to endeavour to a renewal of bilateral agreements. The bilateral agreement requires provisions relating to the protection of migrant workers in the domestic sector through legal and illegal and following the 2017 Consensus on migrant workers.

\section{CONCLUSION}

To protect migrant workers, including for illegal migrant workers in the domestic sector, ASEAN, through its member countries agreed on an instrument of protection and promotion of migrant workers' rights in 2017 entitled ASEAN Consensus on Protection and Promotion of the Rights of Migrant Workers. ASEAN's commitment to promoting and protecting human rights and fundamental freedoms of migrant workers, especially workers in the domestic sector contained in the 2017 ASEAN Consensus must be achieved with maximum efforts.

Indonesia is one of the ASEAN member countries, which is the largest 
sending country for workers in the domestic sector to ASEAN countries. Therefore, Indonesia is expected to implement what was agreed in the 2017 ASEAN Consensus on national legislation and various other domestic policies related to the protection and promotion of migrant workers' rights in the domestic sector. Efforts in implementing the 2017 ASEAN Consensus on migrant workers for Indonesia can be made in two ways: efforts to improve internally and externally. The application of protection standards in the 2017 ASEAN Consensus on migrant workers to improve internally by Indonesia is expected to minimize the number of cases of illegal migrant workers in the domestic sector. The application of protection standards in the 2017 ASEAN Consensus on migrant workers to improve externally by Indonesia is expected to ensure the human rights of migrant workers in the domestic sector remain upheld despite the status of illegal migrant workers. 


\section{REFERENCES}

\section{Article in journals and periodicals}

Labadie-Jackson, Glenda. "Reflections on Domestic Work and The Feminization of Migration". Campbell Law Review 67, (2008): 67 - 90.

Wahyudi, Ridwan. "Illegal Journey : The Indonesian Undocumented Migrant Workers to Malaysia”. Jurnal Populasi 25, (2017): 24-43.

\section{Books and book chapters}

Boer, Mauna. Hukum Internasional (Pengertian Peranan dan Fungsi dalam Era Dinamika Global)[ International Law (Understanding the Role and Function in the Era of Global Dynamics)]. Bandung : PT Alumni, 2005.

Humra. Understanding human rights (manual on human rights education). German, Neuer Wissenschaftlicher Verlag, 2006.

IOM, Migrasi Tenaga Kerja dari Indonesia [Labor Migration from Indonesia]. Jakarta, Organisasi Internasional untuk Migrasi, 2010.

Jack, Donnely. Universal Human Rights in Theory and Practice. Ithaca and London, Cornell University Press, 2003.

Jenks, C.W., The Common Law of Mankind. London, stevens \& sons, 1958.

Kusumaatmadja. Mochtar, Pengantar Hukum Internasional [Introduction to International Law]. Bandung : PT. Alumni, 2012.

Leroy, Bennett A. International organizations (principles \& Issues). New Jersey, Prentice Hall, Englewood Cliffs, 1991.

Nowak, Manfred. U.N. Covenant on Civil and Political Rights : CCPR Commentary. Kehl, Strasbourg, Arlington VA, N.P. Engel, 1993.

Smith, Rhona K.M. et. al. Hukum Hak Asasi Manusia [Human Rights Law]. Yogyakarta: Center for Human Rights Studies at the Islamic University of Indonesia, 2008.

Starke, J.G. Pengantar Hukum Internasional [Introduction to International Law]. Jakarta : Sinar Grafika, 2010.

United Nations Human Rights, Behind Closed doors protecting and promoting the human rights of migrant domestic workers in an regular situation. New York and Geneva, 2015.

Wickramasekera, Piyasiri. Asian Labour Migration: Issues and Challenges in an Era of Globalization. Geneva, ILO, 2002.

\section{Legal Documents}

ASEAN Declaration on the Protection and Promotion of the Rights of Migrant Workers (openened for signature 13 January 2007, date of adoption 18 November 2007)

ASEAN Human Rights Declaration (openened for signature 18 November 2012, date of adoption 18 November 2012)

\section{Web sources}

Amrullah, M. Ridho. Kebijakan Ketenagakerjaan terkait pencegahan TPPO : Migrasi Aman, UU 18/2017, Permenaker No. 9 Tahun 2019 dan 10 tahun 2019 dan Sistem Penempatan Satu Kanal[Employment Policy related to TPPO prevention: 
Safe Migration, Law 18/2017, Permenaker No. 9 of 2019 and 10 of 2019 and the One Channel Placement System]. Accessed 26 June 2020, https://e-learningtppo. kemenpppa.go.id/pluginfile.php/455/mod_resource/content $/ 1 / 2 . \% 20$ Materi $\% 20$ Kementerian\%20Ketenagakerjaan\%20-\%20Rakornas\%20GT\%20PP\%20 TPPO $\% 20 \mathrm{NTT} \% 202019 . \mathrm{pdf}$.

Batam Pos. "29 TKI ilegal gagal ke Malaysia" [29 Illegal migrant workers fail to Malaysia]. Accessed 20 August 2019, https://batampos.co.id/2019/08/27/29-tkiilegal-gagal-ke-malaysia/

BNP2TKI. "Data Penempatan dan Perlindungan PMI periode tahun 2018"[Data on Placement and Protection of Indonesian Migrant Workers for 2018]. Accessed 21 August 2019 http://portal.bnp2tki.go.id/uploads/data/data 12-03-2019 094615 Laporan_Pengolahan_Data_BNP2TKI_2018.pdf.

Buruh Migran. Program Back for Good untuk PATI kembali ke Negara Asal [The Back for Good program for PATI returns to the Country of Origin]. Accessed (25 June 2020, https://buruhmigran.or.id/2019/08/13/program-back-for-good-untukpati-kembali-ke-negara-asal/,

KBRI Kuala Lumpur. Bagaimana Menjadi Tenaga Kerja Indonesia[How to Become an Indonesian Worker], Accessed 29 june 2020, http://kbrikualalumpur. org/w/2017/02/24/bagaimana-menjadi-tenaga-kerja-indonesia/.

Rakasiwi, Dicky Sigit. "Bandar TKI Ilegal yang Tewas Dianiaya Majikan di Malaysia ditangkap" [The dealer of an Illegal Migrant Worker Killed Abused Employer in Malaysia has been arrested]. Accessed 20 August 2019. https://daerah.sindonews.com/read/1419773/174/bandar-tki-ilegal-yang-tewas-dianiaya-majikan-dimalaysia-ditangkap-1562934269.

IOM. "Migrasi Tenaga Kerja dari Indonesia (Gambaran Umum Migrasi Tenaga Kerja Indonesia di Beberapa Negara Tujuan di Asia dan Timur Tengah)" [Labor Migration from Indonesia (Overview of Indonesian Labor Migration in Several Destination Countries in Asia and the Middle East)]. Accessed 25 August 2019, https:// www.iom.int/jahia/webdav/shared/shared/mainsite/published docs/Final-LMReport-Bahasa-Indonesia.pdf.

Tempo. Protes Pungutan TKI di Malaysia, Pemerintah Indonesia Menggertak [protesting TKI levies in Malaysia, the Indonesian government bluffing]. Accessed 28 June 2020, https://nasional.tempo.co/read/872434/protes-pungutan-tki-dimalaysia-pemerintah-indonesia-menggertak. 
Arini Azka Muthia 